\title{
Production Analysis, Minimum Cost, and Profit in Sentra Production of Rice and Corn Farming in Padang Pariaman
}

\author{
Yulia Elita ${ }^{1}$, Sri Ulfa Sentosa ${ }^{2}$, Efrizal Sofyan ${ }^{3}$ \\ ${ }^{1}$ Universitas Negeri Padang, Padang, Indonesia, $\square$ yuliaelita44@yahoo.co.id \\ ${ }^{2}$ Universitas Negeri Padang, Padang, Indonesia, $\square$ sriulfasentosa66@gmail.com \\ ${ }^{3}$ Universitas Negeri Padang, Padang, Indonesia, $\square$ efrizal_syofyan@yahoo.com
}

\begin{abstract}
This study aims to analyze the influence of input to output in the production process of rice and maize farming in the central paddy and corn production areas of Padang Pariaman Regency. This study also calculates the minimum production costs and the profit received. The data used are primary data and secondary data. The data analysis technique used is Multiple Linear Regression Analysis with Cobb-Douglas production function analysis. The results showed that land, seeds, fertilizers, and labor had a positive effect on rice and corn farming production. The minimum cost of rice farming is lower than corn farming. Corn profit is higher than rice profit.
\end{abstract}

Keywords: Factors of Agricultural Production, Minimum Cost and Profit

\section{Introduction}

Utilization of agricultural resources is the keyin increasing agricultural productivity so that limited resources must be allocated as efficiently as possible. Padang Pariaman Regency is noted to have 22,856 hectares of paddy fields in 2017 (BPS, 2018). In that year Padang Pariaman Regency could produce 321,376 tons of rice and 80,270 tons of corn. Corn is a strategic commodity that has economic value (Directorate General of Food Crops, 2002).

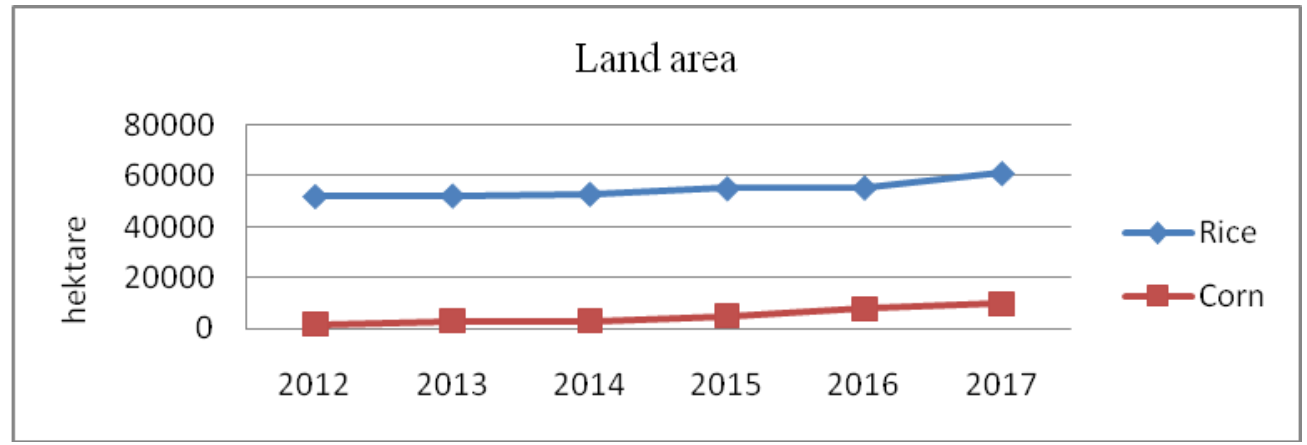

Source: (Central Bureau of Statistics, 2018)

Figure 1 Rice and Corn area in Padang Pariaman Regency (ha)

The agricultural sector as a potential market, especially food agriculture which is a strategic commodity to meet basic human needs (Khazanani, 2011) and (Riyadi, 2003). Demand for food from year to year is increasing, especially the main carbohydrate foods such as rice and corn (Derna, 2007). Based on land area and agroecosystem diversity, opportunities for agricultural development are very large (Karama, 2004). Availability of land has an important role in increasing production (Dombi, 2018). Agricultural land is a determinant of the influence of agricultural commodity production factors (Rahim \& Hastusi, 2007) and (Kusnadi, Tinaprilla, Susilowati, \& Purwoto, 2011). 


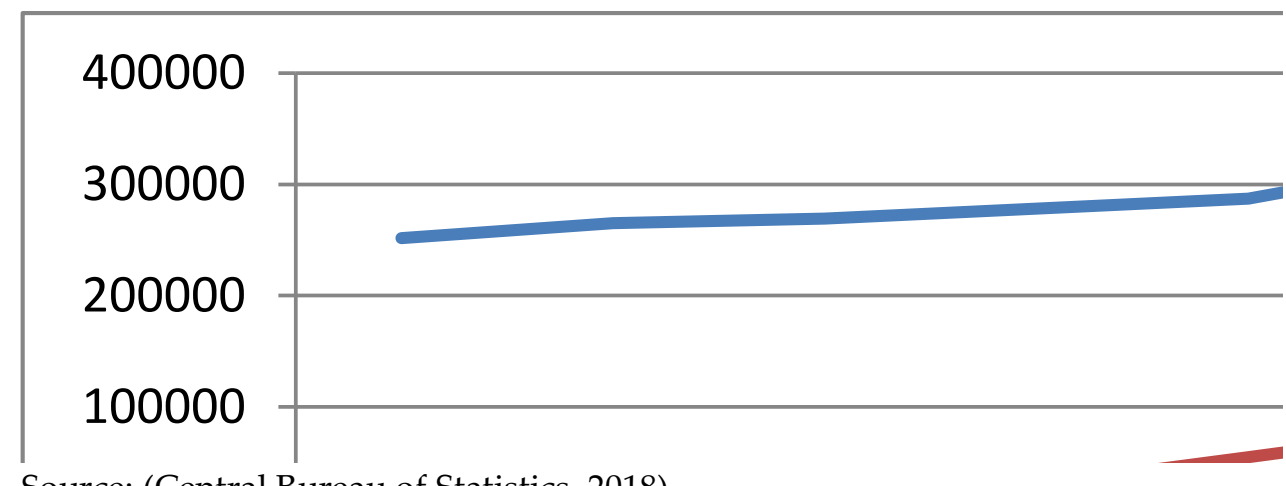

Source: (Central Bureau of Statistics, 2018)

Figure 2 Rice and Corn Production in Padang Pariaman District (tons/ha)

Production is the process of converting the input into output (Pindyck \& Rubinfeld, 2007) and (Debertin, 2012). Production is a technical relationship between the variables described and the variables that explain (Salvatore, 2007). The end result of a farming process is production or output (Handayani, Irwan, \& Begem, 2017). Production factors determine productivity or output, which are the determinants of production factors (Telles, Reydon, \& Maia, 2018). In addition to land, labor also plays an important role in the production process.

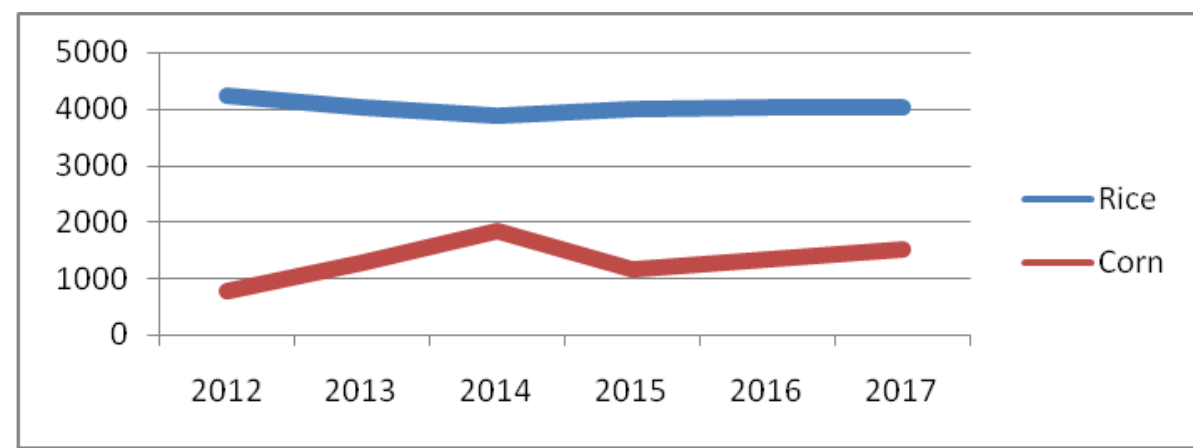

Source: (Agriculture and Food Security Office of Padang Pariaman, 2017)

Figure 3 Number of households absorbed in farming

Rice and Corn in Padang Pariaman District (people)

One of the roles of agriculture is the employment of providers and drivers of regional development (Harja \& Haryoko, 2009). The company decides the amount of labor requested/employed by considering how the number of workers influences its production (Mankiew, 2006). Agricultural production is strongly influenced by the availability of labor (S. Liu, Jiao, Min, \& Yin, 2017). Apart from being fulfilling basic needs, farming can also provide benefits/income for farmers through the sale of farm products (Chendo G.N, N \& M.N., 2017). Agricultural production is influenced by several factors including land rent, labor productivity, and the age of the workforce (Giannakis \& Bruggeman, 2018). The combination of the use of labor is also important so that it can determine the output. Indirectly the absence of labor in agriculture can threaten the sustainability of some important agriculture globally.

As important as labor, good seeds also support production. In order for rice and corn agricultural commodities to produce good quality or quality production, good seeds are needed. 


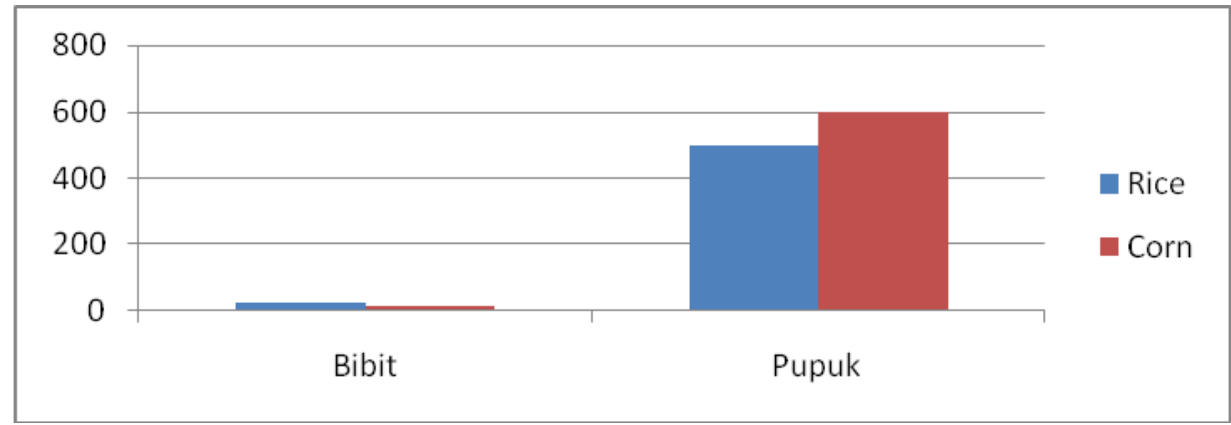

Source: Recommendation from the Ministry of Agriculture \& Field Survey

Figure 4 Number of Seeds and Fertilizers Used by Rice Farmers and Corn 2017 / Ha (Kg)

Seeds provide a very significant influence on corn production assuming other variables are considered constant (Antara, 2010). The amount of this fertilizer has been accumulated from several types of fertilizers used. Fertilization aims to replace lost nutrients and increase the nutrient supply needed by plants to increase crop production and quality (Dewanto, Londok, Tuturoong, \& Kaunang, 2013).

The production input used by a rice and corn farmer is not the only one that guarantees the high economic benefits obtained by the farmer, the profit is also determined by the market price of the commodity sold.

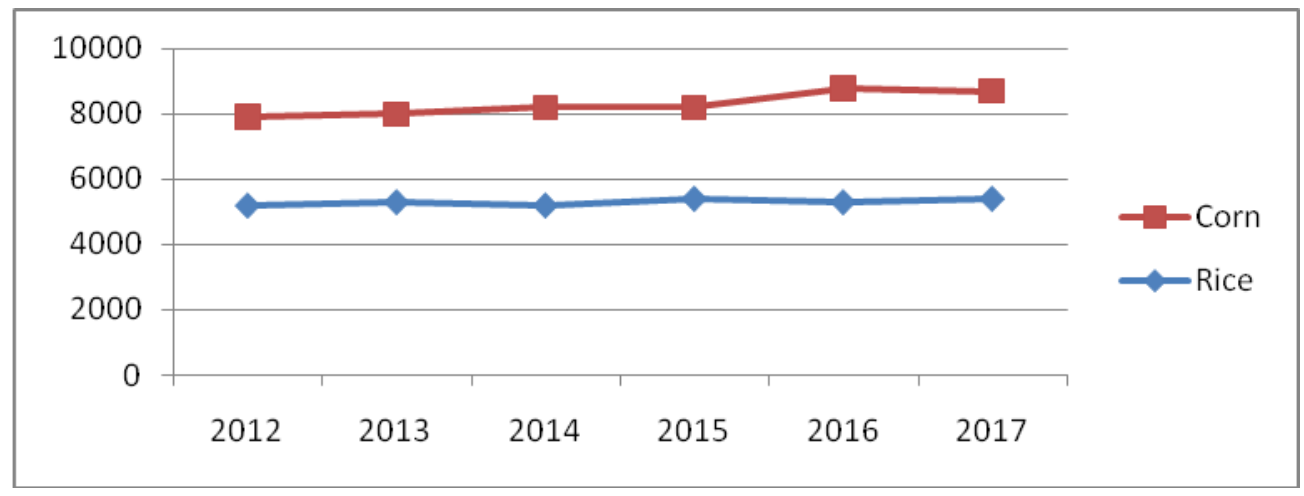

Source: (Agriculture and Food Security Office of Padang Pariaman, 2017) and field surveys

Figure 5 Average Prices of Rice and Corn Commodities in Padang Pariaman Regency (IDR)

Profit (profit) is the difference between total revenue (revenue) and total costs (Pindyck \& Rubinfeld, 2007). The maximum profit of a company is to choose a combination of inputs and outputs with the aim of obtaining maximum economic benefits (Nicholson, 2002). Measuring minimum costs has a direct effect on operations and income (Storto, 2018). Continuous maintenance of inputs can also minimize costs (Lindner, Brits, Vuuren, \& Bekker, 2018). Rice farming income is the difference between revenue and all costs at the time of one planting period (Handayani et al., 2017) and (Diantoro, Sunarsih, \& Soejono, 2015).

Based on the description of the background above, the authors are interested in conducting research with the title of Production Analysis, Minimum Cost and Profit of Rice and Corn Farming in the Padang Pariaman District Production Center.

\section{Methods}

This study uses primary data and secondary data. The total population in this study was 1,379 paddy farmers and 857 corn farmer households consisting of 3 sub-districts in the production center. 
The sampling technique in this study used a multistage cluster random sampling technique (Moh, 2009 ) in. A sample of 82 rice and maize farmers was obtained.

Mathematically the multiple linear regression equation models to determine the effect of input to output in this study is used the following equation:

a. Rice Multiple Linear Regression Analysis

$$
\mathrm{Y}_{1}=\mathrm{f}\left(\mathrm{K}_{1}, \mathrm{~K}_{2}, \mathrm{~K}_{3}, \mathrm{~L}_{4}\right)
$$

This functional relationship can be developed into:

$$
\log \mathrm{Y}_{1}=\mathrm{A}+\beta_{2} \log \mathrm{K}_{2}+\beta_{3} \log \mathrm{K}_{3}+\beta_{4} \log \mathrm{L}_{4}+\mathrm{e}
$$

b. Analysis of Multiple Corn Linear Regression

$$
\mathrm{Y}_{2}=\mathrm{f}\left(\mathrm{K}_{1}, \mathrm{~K}_{2}, \mathrm{~K}_{3}, \mathrm{~L}_{4}\right)
$$

This functional relationship can be developed into:

$\log \mathrm{Y}_{2}=\mathrm{B}+\alpha_{1} \log \mathrm{K}_{1}+\alpha_{2} \log \mathrm{K}_{2}+\alpha_{3} \log \mathrm{K}_{3}+\alpha_{4} \log \mathrm{L}_{4}+\mathrm{e}$

Where $\mathrm{A}$ and $\mathrm{B}=$ constants, $\mathrm{Y} 1=$ production of rice farming, $\mathrm{Y} 2$ = production of corn farming, $\mathrm{K} 1$ = land, $\mathrm{K} 2$ = seeds, $\mathrm{K} 3=$ fertilizer, $\mathrm{L} 4=$ labor, $\mathrm{e}=$ error term indicates bias that occurs due to possible sampling errors . $\beta 1 \ldots \beta 2$ and $\alpha 1 \ldots \alpha 1$. = research variable coefficient.

To find out the minimum cost, the following production functions are used:

$\mathrm{Q}=\mathrm{f}\left(\mathrm{A} K^{\alpha} L^{\beta}\right)$

Then the production function is transformed in the form of structural equations namely:

$\log \mathrm{Q}=\log A+\alpha \log K+\beta \log L+\varepsilon$

Where: A: intercept which presents the technology, regression coefficient $K$, regression coefficient L, error term

An extreme determinant test is carried out with limits to calculate minimum costs. The objective function $f(x, y)$ with the boundary function $g(x, y)=k$ dan $F(x, y, \lambda)=f(x, y)+\lambda[k-g(x, y)]$

$H=\left[\begin{array}{ccc}0 & g_{x} & g_{y} \\ g_{x} & f_{x x} & f_{x y} \\ g_{y} & f_{x y} & f_{y y}\end{array}\right]$

To calculate the profit of rice and corn farming in the central area of Padang Pariaman Regency, it can be formulated as follows:

$\Pi=$ TR - TC

Where $\Pi=$ profit, $\mathrm{TR}=$ p.q, $\mathrm{TC}=$ total variable cost

Table 1 Determinant Test

\begin{tabular}{lcc}
\hline Condition & Maximum & Minimum \\
\hline $\begin{array}{c}\text { First order } \\
\text { partial } \\
\text { revitalization }\end{array}$ & $\frac{\partial F}{\partial x}=0 \frac{\partial F}{\partial y}=0$ dan $\frac{\partial F}{\partial \lambda}=0$ & $\frac{\partial F}{\partial x}=0 \frac{\partial F}{\partial y}=0$ dan $\frac{\partial F}{\partial \lambda}=0$ \\
\hline $\begin{array}{c}\text { Determinant } \\
\text { of the Hessian } \\
\text { Matrix }\end{array}$ & $|H|>0$ & $|H|<0$ \\
\end{tabular}

Source: (Sriyono, 2009) 


\section{Results and Discussion}

\section{Classic assumption test}

Based on the results of the classic assumption test used, namely the normality test, multicollinearity test, heteroscedasticity test, it was concluded that there was no violation of the test, then it could be continued with multiple linear regression tests.

Based on Table 1, the equation can be made as follows:

$\log \mathrm{Y}_{1}=8.38+0.02 \log \mathrm{K}_{1}+0.10 \log \mathrm{K}_{2}+0.26 \log \mathrm{K}_{3}+0.40 \log \mathrm{L}_{4}$

$\log \mathrm{Y}_{2}=8.87+0.19 \log \mathrm{K}_{1}+0.04 \log \mathrm{K}_{2}+0,20 \log \mathrm{K}_{3}+0,32 \log \mathrm{L} 4$

Table 2 Estimation results of multiple linear regression

\begin{tabular}{|c|c|c|c|c|c|}
\hline \multicolumn{3}{|c|}{ Rice } & \multicolumn{3}{|c|}{ Corn } \\
\hline Variable & Coefficient & Probability & Variable & Coefficient & Probability \\
\hline Constant (C) & 8.38 & 0,00 & Constant (C) & 8.87 & 0,00 \\
\hline Land $\left(\mathrm{K}_{1}\right)$ & 0.02 & 0,00 & Land $\left(\mathrm{K}_{1}\right)$ & 0.19 & 0,00 \\
\hline Seeds $\left(\mathrm{K}_{2}\right)$ & 0.10 & 0,00 & Seeds $\left(\mathrm{K}_{2}\right)$ & 0.04 & 0,00 \\
\hline FertilizerK 3 ) & 0.26 & 0,00 & FertilizerK 3 ) & 0.20 & 0,00 \\
\hline labor(L4) & 0.40 & 0,00 & labor $\left(\mathrm{L}_{4}\right)$ & 0.32 & 0,00 \\
\hline \multicolumn{3}{|c|}{ Note: level of trust $\alpha=0,05$} & \multicolumn{3}{|c|}{ Note: level of trust $\alpha=0,05$} \\
\hline \multicolumn{3}{|c|}{$F($ Prob $)=0,00$} & \multicolumn{3}{|c|}{$F($ Prob $)=0,00$} \\
\hline \multicolumn{3}{|c|}{ R-Squared $=0,64$} & \multicolumn{3}{|c|}{ R-Squared $=0,54$} \\
\hline
\end{tabular}

Source: processed author, 2018

\section{Estimated Minimum Cost of rice}

Estimated results of rice production in the form of structural equations:

$\mathrm{Q}=7890,63 K^{0,46} \mathrm{~L}^{0.63}$

$\mathrm{C}=980.315 \mathrm{~K}+8.738 .443 \mathrm{~L}$

Then

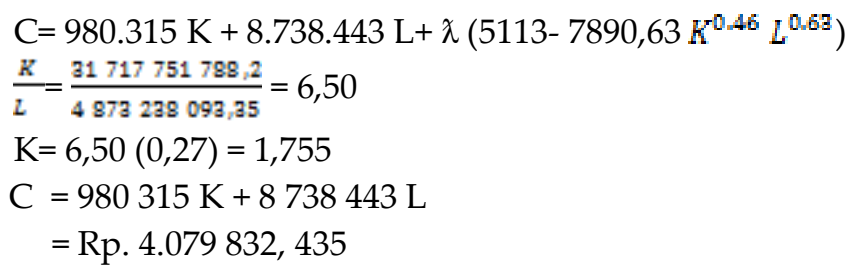

The following is the minimum verification using the Hessian border matrix:

$3629,68 \mathrm{~K}^{-0,54} \mathrm{~L}^{0,63}-4971,09 \mathrm{~K}^{0,46} \mathrm{~L}^{-0,37}=0$

$\mathrm{f}(\mathrm{x}, \mathrm{y})=7890,63 \mathrm{~K}^{0,46} \mathrm{~L}^{0,63}$

$\mathrm{fx}(\mathrm{x}, \mathrm{y})=\frac{7890,63 \times \mathbb{x} 0,46}{K^{0,54}} \mathrm{~L}^{0,63}=\frac{\mathrm{a} 629,68}{K^{0,54}} \mathrm{~L}^{0,63}$

$\mathrm{fxx}(\mathrm{x}, \mathrm{y})=\frac{\mathrm{a} 629,68 \mathrm{x} 0,54}{x^{0,46}} \mathrm{~L}^{0,63}$

$f x x=\frac{1960,03}{(2157,8)^{0,46}}(2955,21)^{0,63}=8812,4$

$f y(x, y)=\frac{4971,09 K^{0,46}}{L^{0,37}}$

fyy $(x, y)=\frac{1999, a\left[(2157,8)^{0,4 E}\right.}{(2955,21)^{0,63}}=409,09$

$\mathrm{fxy}=3629,68 \mathrm{~K}^{-0,54} \mathrm{~L}^{0,63}=\frac{2286_{3} 7}{\left[6 \mathrm{~B}_{2}, 15\right)_{\left(15 \mathrm{~B}_{2}, 6 \mathrm{~B}\right)}}=0,2357$

$|\mathrm{H}|=2(0,2357)-8812,4-409,09=-9221,01 \rightarrow$ Berarti $\rightarrow|\mathrm{H}|<0$ (proven minimum) 


\section{Estimated Minimum Cost of Corn}

Estimated results of corn production in the form of equations:

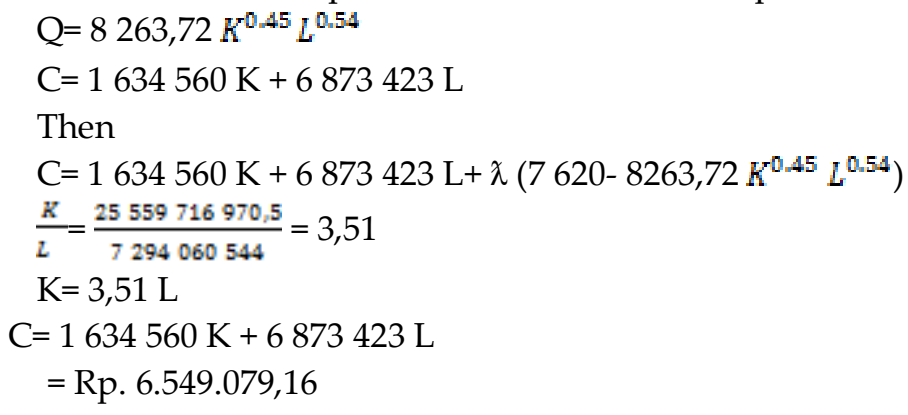

The following is the minimum verification using the Hessian border matrix:

$3718,67 \mathrm{~K}^{-0,55} \mathrm{~L}^{0,54}-4462 \mathrm{~K}^{0,45} \mathrm{~L}^{-0,46}=0$

$\mathrm{f}(\mathrm{x}, \mathrm{y})=8263,72 \mathrm{~K}^{0,45} \mathrm{~L}^{0,54}$

$f x(x, y)=\frac{a 718,67}{R^{0,55}} L^{0,54}$

$\mathrm{fxx}(\mathrm{x}, \mathrm{y})=\frac{2045,27}{K^{0,45}} \mathrm{~L}^{0,54}$

$f x x=\frac{12045,27}{(14008,3)^{0,55}}(4156,53)^{0,54}=2098,69$

$f y(x, y)=\frac{4.462 K^{0,45}}{\mathbb{L}^{0,46}}$

fyy $(x, y)=\frac{2052,52(a, 408, a)^{0,45}}{(4156)^{1,46}}=415,57$

$\mathrm{fxy}=3718,67 \mathrm{~K}^{-0,55} \mathrm{~L}^{0,54}=\frac{200 \mathrm{~g}_{, 1}}{(097,67)(46,19)}=0,496$

$|\mathrm{H}|=2(0,496)-2$ 098,69-415,57 = -2 513,26 $\rightarrow$ means $\rightarrow|\mathrm{H}|<0$ (proven minimum)

\section{Profit of rice and Corn Farming}

Table 3 Profit of paddy and Corn Farming

\begin{tabular}{ll}
\hline \multicolumn{1}{c}{ Rice } & \multicolumn{1}{c}{ Corn } \\
\hline TR = Rp. 25.866.598 & TR =Rp. 31.358.996 \\
\hline TC =Rp.12.718.759 & TC=Rp. 12.239.816 \\
\hline П = Rp. 13.147.839/ha & П= Rp. 19.119.180/ ha \\
\hline
\end{tabular}

Source: processed author, 2018

\section{Effect of land, seedlings, fertilizers, and labor on rice production in the central area of Padang Pariaman}

Based on the results of hypothesis testing the land has a significant effect on rice farming production in the central area of Padang Pariaman Regency with a value of prob $<\alpha(0.00<0.05)$. The policy of land zone distribution can increase productivity (Boonyanam, 2017). Finding that agricultural land is a determinant of the influence of agricultural commodity production factors (Rahim \& Hastusi, 2007). Land quality affects agricultural productivity (Looga, Jürgenson, Sikk, Matveev, \& Maasikamäe, 2018). The extent of land can maximize production (Smith, Jones, Kirk, Pearce, \& Williams, 2018). Land and temperature conditions correlate well in agriculture (Telles et al., 2018). Good land acquisition is certainly good for long-term agricultural production (Boncinelli, Bartolini, \& Casini, 2018).

Seedlings have a significant influence on rice farming production in the central area of Padang Pariaman Regency with a prob value $>\alpha(0,00>0,05)$. Increasing the accuracy of seeding is not possible without the knowledge of work principles (Kosti, Radomirovi, Savin, \& Crnojevi, 2018). Excess nurseries on the amount of planting will reduce the efficiency of these seeds (Shreckhise, Owen, \& Niemiera, 2019). In addition to the number and distance of seed quality, it should also be considered so that it has a good impact on agriculture (Sadowski \& Baer-nawrocka, 2017). Seeds give a very real influence on production assuming other variables are considered constant. 
Fertilizer has a significant influence on rice farming production in the central area of Padang Pariaman Regency with a value of sig $<\alpha(0.00<0.05)$. Fertilizers made from copper-based leaf compost with zinc addition together with controlled urea release will improve soil chemistry (Zhu, Zhang, \& Ma, 2012). Fertilizers can inhibit outbreaks in agricultural crops (Wu, Zhao, Farmer, \& Sun, 2015). The use of energy and fertilizers does not necessarily maximize production, because sometimes the fertilizer decreases under certain conditions (Yuan \& Peng, 2017). If the use of fertilizers is not appropriate, it will interfere with soil fertility or the value of soil fertility will decrease which will also result in reduced production.

Labor has a significant influence on rice farming production in the central area of Padang Pariaman Regency with a sig $<\alpha(0.00<0.05)$. Labor and age determine results. (Boncinelli et al., 2018) unskilled labor is a structural obstacle in agriculture (Dupraz \& Latruffe, 2015). The standard output of work units is determined by labor education (Giannakis \& Bruggeman, 2018). Each of these laborers has its own expertise and specialization. Labor that is often used in agriculture is rent labor or contract labor. Labor is a production factor that needs to be taken into account in the production process. The quality and type of labor must also be considered (Habib, 2013). The influence of labor and capital in agricultural inheritance systems can maximize profits along with the sustainability of agricultural heritage (S. Liu et al., 2017). One agricultural commodity that is inherited from generation to generation is a rice farming commodity.

The coefficient of determination R2 is 0.64 that rice production as much as 64 percent are influenced by the land, seeds, fertilizers, and labor and 36 percent is again influenced by other variables not included in this study.

\section{Effect of land, seeds, fertilizer, and labor on corn farming production in the central area of Padang Pariaman}

Based on the results of hypothesis testing, the land has a significant effect on corn farming production in the central area of Padang Pariaman Regency with a prob value $<\alpha(0.00<0.05)$. Each location of land affects rental prices, transportation costs and labor costs (Boonyanam, 2017). Maps of urban and rural land tenure are also important to note (J. Liu, Hu, \& Green, 2018). Without land, it seems impossible to do farming. Every land expansion (K1), hybrid corn production will also increase. The land is a key factor in agriculture (Yuliana, 2003).

Seedlings have a significant influence on corn farming production in the central area of Padang Pariaman Regency with a prob value $>\alpha(0,00>0,05)$. The pattern of planting arrangements significantly affects the number of fruit crops (Lindner et al., 2018). Farmers must be able to combine the production factors used, namely land area, seeds, fertilizers to achieve the desired results (Setiawan \& Prajanti, 2011). In addition, the proportion of seed used for corn farming must also be reduced. Air pressure and distance in hatchery greatly influence the abundance of production (Kostic et al., 2018). The accuracy of seeding and the technology used when seeding seed affects the increase in production (Tunzelmann \& Wang, 2007).

Fertilizers have a significant effect on rice farming production in the central area of Padang Pariaman Regency with a value of prob $<\alpha(0.00<0.05)$. The combination of the use of fertilizers affects agricultural products (Pozzer, Tsimpidi, Karydis, Meij, \& Lelieveld, 2008). Fertilizers and irrigation water are two important environmental parameters in agricultural production plans (S. Liu et al., 2017). The use of appropriate and timely fertilizers will help increase the success of the final results. The selection pattern and efficiency of fertilizer use affect plant growth (Naik, Jha, Singh, \& Bhatt, 2019). Fertilization aims to replace lost nutrients and increase the nutrient supply needed by plants to increase crop production and quality (Dewanto et al., 2013).

Labor has a significant influence on the production of corn farming in the central area of Padang Pariaman Regency with a sig $<\alpha(0.00<0.05)$. Labor has the highest contribution to growth and resource availability (S. Liu et al., 2017). The allocation of available labor also has an impact on production (Emerick, 2018). Labor does not have a significant effect on corn production (Isyanto, 
2012). The agricultural sector is one of the primary sectors capable of directly contributing to economic growth and welfare of farmer households (Sari, Haryono, \& Rosanti, 2014).

The coefficient of determination R2 is 0.54 . This shows that corn farming production as much as 54 percent are influenced by land, seeds, fertilizers and labor and 46 percent is influenced by other variables not included in this study.

\section{The minimum cost of rice and corn farming in the central area of Padang Pariaman The minimum cost of rice farming}

The minimum cost of rice farming is IDR. 4,079,832,435, - means that farmers in conducting their farming in producing rice commodities must use minimal costs in combining the inputs used so that the desired output can be achieved. Cost calculations are needed to prepare a production budget (Suntivarakorn, Treedet, Singbua, \& Teeramaetawat, 2018). Cost savings can also be felt when there are government policies related to production factors (Science, Phenomena, Grassetti, Mammana, \& Michetti, 2018). Operational cost sharing stages are needed to evaluate each development of the production process (Storto, 2018). What farmers can do inefficiency is by minimizing costs to a certain level (Nicholson, 2002).

\section{The Minimum Cost of Corn Farming}

The minimum cost of corn farming is IDR .6,549,079.16, - meaning that farmers in conducting their farming in producing rice commodities must use minimal costs in combining the inputs used so that the desired output can be achieved. One way to minimize costs is to put the right use of production factors to achieve cost efficiency in production (Pakasi, Pangemanan, Mandei, \& Rompas, 2011). Maintenance costs are also important for sustainable production (Lindner et al., 2018). A high correlation between production costs and total production and corn prices (Kovačević, Jeločnik, \& Subic, 2017). Based on the results of this study, we also see that the high cost of corn farming is due to the high total costs that must be spent by farmers to buy superior seeds and the cost of purchasing fertilizers which are gradually carried out on the corn itself.

\section{The profit of rice and corn farming in the central area of Padang Pariaman}

The results of research on rice farming and corn farming were both given profit to farmers. Where the profit obtained from rice farming is IDR. 13.147.839 while the profit obtained by corn farming is IDR. 19.119.180, - one season. Scheduling each stage of production is important to note (Lindner et al., 2018). Corn production is influenced by land area, seeds, fertilizer and labor (Antara, 2010). Comparison of the average income per month obtained by sweet corn respondent farmers is IDR 9,263.218 / month / ha, more than millions of IDR 6,727.102 / month / ha (57.01\%) compared to rice (opportunity cost) which is IDR 2,536,116 / month / ha (Agustyasari, Antara, \&Anggreni, 2013).

In this study, the high profitability of corn is due to the high output produced which has an impact on the high profits obtained by farmers. Labor costs and excess labor are usually not included in the total cost of full production, which affects the calculation of profits (Kovačević et al., 2017). The high profit of corn is due to the high output produced which has an impact on the high profits obtained by farmers.

\section{Conclusions}

Land, seeds, fertilizers, and labor have a positive effect on rice farming production.Land, seeds, fertilizers, and labor have a positive effect on corn farming production. The cost of rice farming is lower than corn farming. The acquisition of corn profit is higher than the profit of rice.

\section{References}

Agustyasari, N. K., Antara, I. M. and, \& Anggreni, I. G. A. A. L. (2013). Perbandingan Pendapatan Usahatani Jagung Manis dan Padi di Subak Delod Sema Padanggalak Desa Kesiman Petilan Kecamatan Denpasar Timur. E-Jurnal Agribisnis Dan Agrowisata, 2(4), 224-235. 
Antara, M. (2010). Analisis Produksi dan Komparatif Antara Usahatani Jagung Hibrida Dengan NonHibrida Di Kecamatan Palolo Kabupaten Sigi, 17(1), 56-62.

Boncinelli, F., Bartolini, F., \& Casini, L. (2018). Land Use Policy Structural factors of labour allocation for farm diversi fi cation activities. Land Use Policy, 71(October 2017), 204-212. https://doi.org/10.1016/j.landusepol.2017.11.058

Boonyanam, N. (2017). Land Use Policy Agricultural economic zones in Thailand. Land Use Policy, (June 2016), 1-9. https://doi.org/10.1016/j.landusepol.2017.05.023

BPS. (2018). Padang Pariaman Dalam Angka.

Chendo G.N, N, B., \& M.N., L. and O. (2017). Cost And Rerurns Of Paddy Rie Prodution in Kaduna State, 5(3), 41-48.

Debertin, D. L. (2012). Agricultural Production Economis (Second). Lexington University Of Kentucky.

Derna, H. (2007). Pengaruh Konsentrasi dan Waktu Pemupukan POC Super ACI Terhadap Perrtumbuhan dan Hasil Jagung Manis.

Dewanto, F. G., Londok, J. J. M. R., Tuturoong, R. A. V., \& Kaunang, W. B. (2013). Pengaruh Pemupukan AnOrganik dan Organik Terhadap Produksi Tanaman Jagung Sebagai Sumber Pakan, 32(5), 1-8.

Diantoro, K., Sunarsih, M., \& Soejono, D. (2015). Faktor-faktor Yang Mempengaruhi Produksi Padi Pada Kelompok Tani Patemon II Di Desa Patemon Kkecamatan Tlogosari Kabupaten Bondowoso, 3(3), 55-59.

Dinas Pertanian dan Ketahanan Pangan Padang Pariaman. (2017). Dinas Pertanian dan Ketahanan Pangan Kabupaten Padang Pariaman.

Dombi, M. (2018). Resources, Conservation \& Recycling Modeling the material stock of manufactured capital with production function. Resources, Conservation \& Recycling, 138(July), 207-214. https://doi.org/10.1016/j.resconrec.2018.07.015

Dupraz, P., \& Latruffe, L. (2015). Trends in family labour, hired labour and contract work on French field crop farms: The role of the Common Agricultural Policy. Food Policy, 51, 104-118. https://doi.org/10.1016/j.foodpol.2015.01.003

Emerick, K. (2018). Agricultural productivity and the sectoral reallocation of labor in rural India. Journal of Development Economics. https://doi.org/10.1016/j.jdeveco.2018.08.013

Giannakis, E., \& Bruggeman, A. (2018). Land Use Policy Exploring the labour productivity of agricultural systems across European regions: A multilevel approach. Land Use Policy, 77(December 2017), 94-106. https://doi.org/10.1016/j.landusepol.2018.05.037

Habib, A. (2013). Analisis Faktor -faktor Yang Mempengaruhi Produksi Jagung, 18(1), 79-87.

Handayani, S. A., Irwan, E., \& Begem, V. (2017). Produksi dan Pendapatan Usahatani Padi di Desa Pujo Asri Kecamatan Trimurjo Kabupaten Lampung Tengah, 5(4).

Harja, M. Z., \& Haryoko, W. (2009). Pengujian Empat Varietas Padi Unggul pada Sawah Gambut Bukaan Baru di Kabupaten Padang Pariaman Evaluation of Several High Yield Rice Varieties in New Peat Soil Rice Field in Padang Pariaman District, 12(1), 56-61.

Isyanto, A. Y. (2012). Faktor- faktor Yang Berpengaruh Terhadap Produksi Padi di Kabupaten Ciamis, $1(8), 4$.

Karama, A. . (2004). Pembangunan Pertanian Yang Mensejahterakan Bersama Pemerintahan Otonomi Daerah dan Perdagangan Bebas. SUkarami.

Khazanani, A. (2011). Analisis Efisiensi Penggunaan Faktor-faktor Produksi Ushatani Cabai Kabupaten Temanggung. Semarang.

Kosti, M., Radomirovi, D., Savin, L., \& Crnojevi, V. (2018). Corn seeding process fault cause analysis based on a theoretical and experimental approach, 151(June), 207-218. https://doi.org/10.1016/j.compag.2018.06.014

Kostić, M., Rakić, D., Radomirović, D., Savin, L., Dedović, N., Crnojević, V., \& Ljubičić, N. (2018). Corn seeding process fault cause analysis based on a theoretical and experimental approach, (151), 207-218.

Kovačević, V., Jeločnik, M., \& Subić, J. (2017). Causality Between Corn Production Cost and Cash 
Corn Price, 2-16.

Kusnadi, N., Tinaprilla, N., Susilowati, S. H., \& Purwoto, A. (2011). Analisis Efisiensi Usahatani Padi Di Beberapa Sentra Produksi Padi Di Indonesia, Volume 29, 25-48.

Lindner, B. G., Brits, R., Vuuren, J. H. Van, \& Bekker, J. (2018). Electrical Power and Energy Systems Tradeo ff $\mathrm{s}$ between levelling the reserve margin and minimising production cost in generator maintenance scheduling for regulated power systems. Electrical Power and Energy Systems, 101(January), 458-471. https://doi.org/10.1016/j.ijepes.2018.02.018

Liu, J., Hu, T., \& Green, M. (2018). Land Use Policy Potential impacts of agricultural land use on soil cover in response to bioenergy production in Canada, 75(December 2017), 33-42. https://doi.org/10.1016/j.landusepol.2018.03.032

Liu, S., Jiao, W., Min, Q., \& Yin, J. (2017). The Influences of Production Factors with Profit on Agricultural Heritage Systems: A Case Study of the Rice-Fish System. https://doi.org/10.3390/su9101842

Looga, J., Jürgenson, E., Sikk, K., Matveev, E., \& Maasikamäe, S. (2018). Land Use Policy Land fragmentation and other determinants of agricultural farm productivity: The case of Estonia. Land Use Policy, 79(March), 285-292. https://doi.org/10.1016/j.landusepol.2018.08.021

Mankiew, G. N. (2006). Principles Of Economis Pengantar Ekonomi Mikro. (C. Sungkono, Ed.) (Tiga). Jakarta: Salemba Empat.

Moh, N. (2009). Metode Penelitian. Bogor: Ghalia Indonesia.

Naik, S. K., Jha, B. K., Singh, A. K., \& Bhatt, B. P. (2019). Planting geometry and growth stage linked fertigation patterns : Impact on yield, nutrient uptake and water productivity of Chilli pepper in hot and sub- humid climate. Scientia Horticulturae, 249(November 2018), 289-298. https://doi.org/10.1016/j.scienta.2019.02.003

Nicholson, W. (2002). Intermediate Microeconomis And Its Application. (I. B. Mahendra \& A. Aziz, Eds.) (8th ed.). Erlangga.

Pakasi, C. B. D., Pangemanan, L., Mandei, J. R., \& Rompas, N. N. I. (2011). Efisiensi Peenggunaan Faktor Produksi Pada Usahatani Jagung di Kecamatan mboken Kabupaten Minahasa, 7(2), 5160.

Pindyck, S. R., \& Rubinfeld, L. D. (2007). Mikroekonomi. (N. K. Dewi, Ed.) (Keenam). Jakarta: PT Indeks.

Pozzer, A., Tsimpidi, A. P., Karydis, V. A., Meij, A. De, \& Lelieveld, J. (2008). Impact of agricultural emission reductions on fine-particulate matter and public health, 12826

Rahim, A., \& Hastusi, D. R. D. (2007). Ekonomika Pertanian (Pengantarr Teori dan Kasus). Jakarta: Peenebar Swadaya.

Riyadi, H. (2003). Metode Penilaian Status Gizi Secara Antropometrri (Method of Antropomtrric NationalAssessment). Bogor.

Sadowski, A., \& Baer-nawrocka, A. (2017). Land Use Policy Food and environmental function in world agriculture - Interdependence or competition? Land Use Policy, (January), 0-1. https://doi.org/10.1016/j.landusepol.2017.11.005

Salvatore, D. (2007). Teori dan Soal-soal Mikroekonomi. (R. Sitompul, Ed.) (4th ed.). Jakarta.

Sari, D. K., Haryono, D., \& Rosanti, N. (2014). Analisis Pendapatan dan Tingkat Kesejahteraan Rumah Tangga Petani Jagung di Kecamatan Natar Kabupaten Lampung Selatan, 2(1).

Science, N., Phenomena, C., Grassetti, F., Mammana, C., \& Michetti, E. (2018). Chaos, Solitons and Fractals Substitutability between production factors and growth. An analysis using VES production functions. Chaos, Solitons and Fractals: The Interdisciplinary Journal of Nonlinear Science, and Nonequilibrium and Complex Phenomena, 113, 53-62. https://doi.org/10.1016/j.chaos.2018.04.012

Setiawan, A. B., \& Prajanti, S. D. W. (2011). Analisis Efisiensi Penggunaan Faktor-fator Produksi Usahatani Jagung Di Kabupaten Grobogan Tahun 2008.

Shreckhise, J. H., Owen, J. S., \& Niemiera, A. X. (2019). Growth response of Hydrangea macrophylla and Ilex crenata cultivars to low- phosphorus controlled-release fertilizers it. Scientia 
Horticulturae, 246(October 2018), 578-588. https://doi.org/10.1016/j.scienta.2018.10.045

Smith, L. G., Jones, P. J., Kirk, G. J. D., Pearce, B. D., \& Williams, A. G. (2018). Land Use Policy Modelling the production impacts of a widespread conversion to organic agriculture in England and Wales. Land Use Policy, 76(February), 391-404. https://doi.org/10.1016/j.landusepol.2018.02.035

Sriyono, D. (2009). Matematika Eknomi dan Keuangan (p. 189). Yogyakarta: CV. Andi Offset.

Storto, C. (2018). Journal of Air Transport Management The analysis of the cost-revenue production cycle e ffi ciency of the Italian airports: A NSBM DEA approach, (January). https://doi.org/10.1016/j.jairtraman.2018.05.010

Suntivarakorn, R., Treedet, W., Singbua, P., \& Teeramaetawat, N. (2018). Fast pyrolysis from Napier grass for pyrolysis oil production by using circulating Fluidized Bed Reactor : Improvement of pyrolysis system and production cost. Energy Reports, 4, 565-575. https://doi.org/10.1016/j.egyr.2018.08.004

Telles, T. S., Reydon, B. P., \& Maia, A. G. (2018). Land Use Policy E ff ects of no-tillage on agricultural land values in Brazil. Land Use Policy, 76(October 2017), 124-129. https://doi.org/10.1016/j.landusepol.2018.04.053

Tunzelmann, N. Von, \& Wang, Q. (2007). Capabilities and production theory, 18, 192-211. https://doi.org/10.1016/j.strueco.2006.11.002

Wu, Y., Zhao, C., Farmer, J., \& Sun, J. (2015). Effects of bio-organic fertilizer on pepper growth and Fusarium wilt biocontrol. Scientia Horticulturae, 193, 114-120. https://doi.org/10.1016/j.scienta.2015.06.039

Yuan, S., \& Peng, S. (2017). Input-output energy analysis of rice production in different crop management practices in central China. Energy. https://doi.org/10.1016/j.energy.2017.10.007

Yuliana. (2003). Faktor-faktor yang Mempengaruhi Produksi Jagung Hibrida di Kecamatan Sinjai Borong Kabupaten Sinjai. Universitas Negeri Makasar.

Zhu, Q., Zhang, M., \& Ma, Q. (2012). Copper-based foliar fertilizer and controlled release urea improved soil chemical properties, plant growth and yield of tomato. Scientia Horticulturae, 143, 109-114. https://doi.org/10.1016/j.scienta.2012.06.008 